\title{
Validity as a Function of Meaning in Somló's Juristische Grundlehre
}

\author{
TREVOR WeDMAN*
}

\begin{abstract}
Hans Kelsen, along with most other legal theorists, presupposes the existence of the sovereign in developing his theory of law. As a result, the Kelsenian theory can only account for legal norms issued in the abstract. For legal norms in the abstract though, there is no bearing on which to develop a theory of norms that reaches beyond the skeletal. This is an issue which has plagued legal theory for the past century and which this paper proposes to address upon a re-reading of the Juristische Grundlehre. Specifically, we are able to open our concept of sovereignty with Somló in ways that the Kelsenian theory does not permit. In this paper, I will argue that Felix Somló's flexible conception of sovereignty leads to a much fuller contextualization of legal norms as expressions of meaning.
\end{abstract}

Keywords: sovereignty, absolute validity, meaning, agency

In determining how the jus non scriptum can come to be, it is necessary to first clarify the genus of which this kind of law forms only one of its species, i.e. one must first ask about the essence of the law itself. ${ }^{1}$

\section{FRAMING THE ISSUE}

Kelsen asserts that: (i) the Kantian categorical imperative is an 'empty formula'; (ii) any attempt to objectify an ought results in subjecting to logic a category which is illogical; (iii) the only object of rational thought in the social realm are interests and conflicts of interest which can only be solved through ordering the interests one against the other; and (iv) if there would already exist societal order on the basis of reason, then it would be foolish to develop a theory of legal positivism. ${ }^{2}$

* Doctoral student, Leipzig University, trevor.wedman@gmail.com

1 Somló (1927) § 100, FN. 1, citing Bruno Schmidt (translated freely by author): 'Wenn man feststellen will, worin das Wesen des jus non scriptum besteht, wird man sich vor allem über das genus, von welchem es die eine species darstellen soll, d. h. darüber klar sein müssen, was Recht überhaupt ist.'

2 Kelsen (1934) 14, 15: (i) 'Alle derartigen Versuche haben bisher immer nur zu völlig leeren Formeln geführt, wie: ,Tue das Gute und meide das Böse', ,Jedem das Seine', ,Halte die richtige Mitte', u. dgl. Auch der ,kategorische Imperativ ist ganz inhaltslos.'; (ii) 'Die Gerechtigkeit, ein Ideal des Wollens und Handelns, muss sich, zum Gegenstand der Erkenntnis gemacht, unversehens in die Idee der Wahrheit verwandeln, die ihren - negativen - Ausdruck im Identitätssatz findet. Diese Denaturierung des Problems ist die unvermeidliche Folge der Logifizierung eines von vornherein logosfremden Objekts.'; (iii) 'Vom Standpunkt rationaler Erkenntnis aus gesehen, gibt es nur Interessen und damit Interessenkonflikte, deren Lösung durch eine Interessenordnung erfolgt, die entweder das eine Interesse gegen das andere, auf Kosten des anderen befriedigt oder aber einen Ausgleich, ein Kompromiß zwischen den gegensätzlichen Interessen stiftet.'; (iv) 'Angesichts eines Vorhandenseins einer absolut guten, sich schon aus der Natur, der Vernunft, oder dem göttlichen Willen ergebenden gesellschaftlichen Ordnung wäre die Tätigkeit des staatlichen Gesetzgebers der törichte Versuch einer künstlichen Beleuchtung bei hellstem Sonnenlicht.' 
Each of these four positions which Kelsen describes in quick succession in the Reine Rechtslehre (I) has, with or without Kelsen's influence, become a core assumption underlying much of modern legal positivism. Ad (i), since all categorical imperatives, whether the Kantian or some other version such as 'seek the good', are ultimately tautological, it is not possible to use any such norm as a basis for 'finding' norms that are objectively valid independent of the positive law; ad (ii), even if it would be possible to identify norms that are objectively valid independent of the positive law, it would not follow that such norms should become the basis of a legal order - this would entail a category mistake by applying a logic of existence, e.g. the principle of non-contradiction, to normativity; ad (iii), because of (i) and (ii), all legal norms merely reflect social interests and, since all such interests are completely relative to social inputs which by their nature are mutable, the proper object of legal theory is not the interests themselves but rather an ordering of these interests through a system of secondary norms; ${ }^{3}$ ad (iv) legal positivism is justified ex negativo - other forms of legal theory, e.g. natural legal theories, could be justifiable (and would be preferable) were it not for positions (i) - (iii), positions (i) - (iii) being the case, however, legal positivism is the only viable theory.

Upon closer examination, positions (i) and (iii), together with the conclusion (iv) orbit around the central proposition (ii) that a logic of norms entails predicating truth of value and that such an undertaking is impossible, violating the is-ought distinction. I believe that the theory of legal norms which Felix Somló develops in the Juristische Grundlehre attacks the heart of this position by attempting to demonstrate that which Kelsen deemed impossible. In doing this, Somló shows:

a) the viability of categorically imperative order;

b) the logical relation of norms with each other;

c) that legal norms cannot be reduced to mere reflections of immediate social interests; and, importantly,

d) the project of legal positivism is nonetheless crucial for our understanding of legal order even if (a) through (c) hold.

In retracing this argument, I hope to show the necessity of reconsidering Somlo's theory for a revised theory of law for the $21^{\text {st }}$ century.

\section{THE STARTING POSITION}

For the purpose of best realizing the importance of Somlós work for a new interpretation of legal theory, it is perhaps best to start with that other theorist who gives John Austin's work a prominent role in his theory. In The Concept of Law, H.L.A. Hart claimed that law can most adequately be defined as the union of primary and secondary rules. ${ }^{4}$ Primary rules he defines as those under which 'human beings are required to do or abstain from certain

${ }^{3}$ I use here the Hartian terminology of secondary norms as hierarchical norms. The terminology is confusing because Kelsen considers the primary function of legal norms to lie in their hierarchical function, i.e. as directives on which officials are to act. Accordingly, Kelsen allows that norms could be considered to have a secondary aspect as being directed to affect the behaviour of individual subjects. See Kelsen (1934) 30. Somló's terminology is again different, according to which primary rules (or sources of law) are those which come directly from the sovereign (Rechtsmacht) and secondary rules (or sources of law) are those that come from a political body (Staatsorgan), see also Somló (1927) § 100.

4 Hart (1994) 79. 
actions.' Secondary rules include those according to which 'human beings may by doing or saying certain things introduce new rules of the primary type. ${ }^{5}$ According to Hart, primary rules directly concern human actions whereas secondary rules provide for operations according to which duties or obligations to act are created or modified. The two conceptions of rules are essential for Hart because he claims that a legal system precisely consists of certain primary rules which obtain their validity and legal character from other secondary rules. Thus, a certain primary rule such as 'you should not steal' would be a law if there was a corresponding secondary rule to the effect of 'the legislature or other law-making body has the power to impose the duty that you should not steal.' Hart claims that a top-down ordering of the law i.e., the existence of in-themselves normatively binding secondary rules, is necessary to ensure that the corresponding legal order is endowed with certainty, efficiency and dynamism.

By conceiving of the law within this top-down framework, Hart seems to develop his theory within the most straightforward context possible, i.e., it is part and parcel of individual legal norms that they exist within a hierarchical structure of norms. After all, what else could the relation between sovereign and subject be but that between master and servant? One of the constants of legal theory is that the sovereign has the power to enact laws independent of the subject's consent, precisely as a master over a servant. Besides, this framing of the law within a hierarchically normative framework also fits well within Kelsen's basic view and, on Hart's characterization, Austin's as well. Despite the fact that Hart argues primarily against Austin's conception in The Concept of Law, Hart's basic argument is that the necessary complement to Austin's theory of sovereignty, the habit of obedience and commands backed by threats, is the unification of primary and secondary rules through a rule recognizing the hierarchical structure of the legal order. While Hart's Rule of Recognition reduces the legal order to a question of social fact and therefore fundamentally opposes the normative stance of Kelsen's Grundnorm, both Hart and Kelsen are united in their opposition to the possibility of validity actually inhering within a legal order. Despite their many differences, for the present purposes Hart and Kelsen are both the heroes of current mainstream legal theory (characterized by (i) through (iii) above) and the main antagonists of (the following interpretation of) Somló's conception of law.

The opposition of both Hart and Kelsen to an inherent validity of the law is hardly surprising given the shared premise that the legal system consists of a hierarchy of arbitrary norms cascading from sovereign to subject. In such a case, either (1) Rex's laws are endowed with inherent validity (i.e. a non-starting totalitarianism), (2) the validity of Rex's laws is fictional (i.e. Kelsen's ultimate position) or (3) the validity of Rex's laws comes from the factual recognition of the legal system as such (i.e. Hart's position). Given a liberal democratic predilection, Hart and Kelsen cannot but adopt either (2) or (3) or some variation thereof. Nonetheless, each of the above scenarios presumes a certain kind of sovereignty which actually begs the question to an even more fundamental question of the law. By rejecting all three of the options, Somló opens a path towards a new frontier of legal analysis altogether. 


\section{THE FLUX OF SOVEREIGNTY - INDIVIDUALS AND COLLECTIVES}

The elephant in the room for both Kelsen's and Hart's theories is the concept of sovereignty. While Kelsen clearly sees the sovereign (or state) as a legal construct and Hart sees it being closely tied to factual recognition of a hierarchical system, neither are able to successfully answer the question of why it exists in the first place. In the moral aspect, we ask why we should follow the law, in the sociological aspect, we ask why do individuals almost universally group themselves together into collectives, and in the legal aspect, we ask what is the nature of sovereign relations such that some individuals command and others (must) follow. Even if we should dismiss these first two (moral and sociological) aspects as being irrelevant for a legal theoretical investigation, they are bound to nonetheless be present when conducting the 'strictly' legal analysis.

In fairness to Hart, Kelsen and much of $20^{\text {th }}$ century theory, the issue of sovereignty is one of the most perplexing issues of the modern state and indeed suffers from a taint of traditionalism or even totalitarianism. Where sovereignty was once thought to adhere to God or to God's representatives on earth, the absolute power concept of sovereignty as it has existed since Bodin and, on some interpretations, Hobbes, is hardly but a secular equivalent of the same. Nonetheless, it is hardly surprising that in failing to address the nature of sovereignty, why and how it exists, Kelsen and Hart also failed to give' satisfactory accounts of value and validity in the law. Presupposing the existence of an absolute sovereign, Hart and Kelsen presuppose the hierarchical tendency of norms within legal systems and therefore have to start from precisely the wrong assumption.

In contrast to his mainstream counterparts, Somló is able to free himself from these preconceptions of sovereignty and instead begins his investigation in the Juristische Grundlehre not by asking how legal norms are related to the sovereign, but rather how norms generally are related to collectives and the individuals that constitute them. Somló defines the legal norm in $\S 26$ as a normative expression (Willenssatzung) of a sovereign:

Legal norms are expressions of will, [...] which are derived from the still to be determined 'highest power' on which the entire concept of law is based and upon the determination of which everything else depends. ${ }^{6}$

The Juristische Grundlehre begins with a discussion of norms most generally. It is important for Somló that each norm, regardless of its kind, 'wants' to be valid. In other words, the nature of all prescriptions and directives, in short all 'oughts', is that their internal logic is to be followed. Of course, we do not typically follow all norms that are addressed to us or that we perhaps happen to come upon. Rather, we only follow those which we deem significant in one way or another. For this reason, each of us is constantly ordering or systematizing a system of norms, discarding or relegating some norms as out of fashion or antiquated, and prioritizing others as of particular relevance. In a moment of national crisis, we might emphasize norms of patriotism. As society develops and traditions

${ }^{6}$ Somló (1927) § 26, p. 86: 'Die Rechtsnormen sind demnach Willenssatzungen, [...] die von der noch näher $\mathrm{zu}$ bestimmenden 'höchsten Macht' herrühren, auf deren Begriff der ganze Rechtsbegriff abgestellt ist und auf deren Bestimmung nun mehr alles weitere ankommt.' 
are lost, we might choose to disregard the norms of our grandparents, such as removing one's hat upon entering a church. In this sea of norms, each of which is fighting for superiority, ${ }^{7}$ some gain the highest status of being the law. In Somlós definition, these are the norms which issue from the highest power, or sovereign and, as such, the initial function of sovereignty is simply that it is the differentia specifica of legal norms in contrast with all other norms.

Any time there is a collective, e.g. a church community, a country club, a criminal gang, a professional or industry association, a league of nations, the collective must necessarily issue norms that are heteronomous to its individual members as a means of organizing behavior for the good, or integrity, of the organization. Since the norms are heteronomous to the members' own will, it will not always be convenient or desirable for them to act accordingly. In such a situation, they may choose to leave the collective, even though there is a general habit of obedience on their part and that of others, as long as the collective, e.g., the country club, is only a relative power. As long as it is an option to switch to a different country club or to quit playing golf altogether, the by-laws of the country club do not in themselves enjoy the force of law. A country club only applies to a particular set of individuals and it is voluntary. Since there is no general habit of obedience on the part of everyone i.e., non-members, and since even those for whom there is a general habit of obedience may at any time exit the collective, a country club is an unlikely candidate for sovereignty. However, there are other collectives, the rules of which apply to everyone and from which there is no exit clause - these are the highest powers, the sovereigns, from which legal norms issue. That such sovereigns exist is not an empirical matter of fact, but, as with Kelsen's Grundnorm, a legal a priori resulting from the necessity of the jurist to understand and order the social world as a normative unity, without the possibility of conflict.

Somlós definition of law quite clearly follows Austin's conception of law as the commands of a sovereign which enjoys a habit of obedience. However, whereas this Austinian framework is typically interpreted as "imperial' ${ }^{\prime 8}$ or hierarchical in nature, Somló gives the Austinian frame a decidedly non-imperial, non-hierarchical flavor. As such, for Somló, order is not a function of sovereignty, but rather sovereignty is a function of order. If there is no order as a matter of fact, then there is no sovereign and thus also no legal norm - a scenario of the Hobbesian state of war. ${ }^{9}$ However, if an order does exist, then

7 See Somló (1927) § 28, p. 90: 'Wir kommen also zu dem Ergebnis, dass jede Normart den übrigen gegenüber Selbstherrlich ist, und folglich die übrigen auch verletzen kann. The slightly more metaphorical phrasing can be found in Somló (1926): 'Begriffe sind harmlose, weder streitsüchtige, noch herrschsüchtige Bedeutungen, es sind friedlich, neben einander stehende Lämmchen in den Gefilden der lauteren Bedeutungen; sie tun sich gegenseitig nichts Zuleide. Anders die Sätze. Jeder von Ihnen hat die Mitbedeutung der unbedingten Geltung, der Richtigkeit. In jedem besonderen Satzsinne ist der Sinn mit Inbegriffen, dass es ein unbedingt gültiger Satz sei. Es ist ein Geschlecht von kampflustigen, herrschsüchtigen, sich befehdenden oder sich gegen andere verbündenden Bedeutungen.'

8 See Bix (2018).

9 See Somló (1927) § 31, p. 99: 'Alle Zeiten, in denen diese bestimmt geartete oberste Macht in Bezug auf bestimmte Menschenkreise nicht zustande kommt, sind rechtlose. Wenn z. B. ein Bürgerkrieg lange und unentschieden wütet, wenn allgemeiner Aufruhr an Stelle der Ordnung tritt, wenn eine äußere Macht die bestehende Staatsgewalt niederwirft, sich aber nicht behaupten kann und auch sonst keine Macht zustande kommt, deren Normen allgemein befolgt werden, so besteht eben zu solchen Zeiten kein Recht. Allerdings wird sich ein solcher Zustand nicht lange erhalten. Die allgemeine Zügellosigkeit und Unordnung würde den betreffenden Kreis bald vernichten. Denn, und 
there must be a principally unifying factor which Somló calls the highest power (höchste Macht) or sovereign. That there is a sovereign though, does not establish wherein, or with whom, sovereignty lies. Actually locating this highest power for a given society at a given time can be arduous. Nonetheless, the fact that one sovereign exists for any ordered society is a matter of certainty resulting from the fact that every society is a collective and every collective in some necessary way exerts power over its individuals.

There is a certain circularity in Somló's logic. The legal norm issues from the sovereign which is present if and only if there is a legal order, presumably a collection of legal norms that are present if and only if there is a sovereign. Which comes first the sovereign or the law? This question of priority or genesis does not present itself with the classical imperial, hierarchical or monarchical picture in which God or Rex (king) rescue lost souls from a state of disorder. In contrast with this classical view, Somlós conception opens a pandora's box of unknowns, which have no apparently clear solution. Somló says that any jurisprudential analysis of constitutional law requires as its foundation an historical and sociological investigation of the particular qualities of sovereignty in that state. ${ }^{10} \mathrm{He}$ states that to say that the author of a legal norm is a sovereign is only to refer to such author's ability to generally realize (succeed with) his norms or, in other words, to cause them to be followed. ${ }^{11}$ Further, Somló says that there is a close mental connection between the habit of obedience and all other factors of societal and political culture, thus giving the notion of obedience its inexhaustible nuance. ${ }^{12}$ Finally, he qualifies that a sovereign may be the sovereign as long as it (or he or she) enacts law in a particular way. As soon as the sovereign goes against certain beliefs or preconceptions though, it may cease to be the sovereign. ${ }^{13}$

Whereas Kelsen, Hart and most of mainstream legal positivism establish clear rules for recognizing legal authority within a territory, Somló's theory is almost created as if to establish the greatest degree of uncertainty possible. Most theorists, even natural law theorists, acknowledge the importance of clear rules establishing a line of authority from the highest legislator to the lowest administrator. Somló, on the other hand, would hold that a line of authority can only be of use on the assumption that the highest legislator identified by such rules is actually the sovereign in the territory and that such sovereign has actually issued a corresponding system of secondary norms. However, if the legal norms are really the commands of a sovereign which enjoys a habit of obedience, then there can certainly be

das sei besonders betont, nur allgemeine Zügellosigkeit und Aufruhr kann Platz greifen, wenn das Recht aufhört zu sein. Es muss kein Recht geben, aber die Alternative lautet: entweder rechtlich geregelter Zustand oder jener bellum omnium contra omnes des Hobbes.'

10 Somló (1927) § 95, p. 314: 'Jede juristische Behandlung eines gegebenen Staatsrechts erfordert als Grundlage eine historisch-soziale Untersuchung über die Beschaffenheit der Rechtsmacht in jenem Staate.'

11 Somló (1927) § 36, p. 108, 109: 'Die Bezeichnung des Urhebers von Rechtsnormen als einer Macht bedeutet weiter nichts, als seine Fähigkeit zum gewöhnlichen Verwirklichen seiner Normen, mit anderen Worten: zur Verursachung ihrer Befolgung.'

12 Somló (1927) § 37, p. 111, citing F. Klein: 'Der Rechtsgehorsam ist mit allen Faktoren der Gesellschaftskultur und des Staatslebens in engem geistigen Zusammenhang, und das gibt ihm seine unerschöpflichen Nuancen.'

13 Somló (1927) § 40, p. 119: 'Solange ein Machthaber in einer bestimmten Weise Recht schafft, mag er als Rechtsmacht gelten. Sobald er aber gewisse Überzeugungen verletzt, hört er auf, Rechtsmacht zu sein.' 
norms that exist outside of the standard hierarchical framework of legislator, administrator, judge. Since no sovereign can be bound by a clean 'scientific' (hierarchical) ordering of norms, it is always possible for a sovereign to contradict such a system through the express or implied issuance of law. As such, immediate legislation, which Somló calls a primary source of law, always trumps mediate legislation (secondary sources in Somló's terminology). ${ }^{14}$ Combining this openness with respect to the sources of law, the additional factor that both mediate and immediate sources of law can issue both express and implied norms, then the determination of the content of the law goes from a fairly dry, clerical activity of deducing one paragraph from another to a seemingly impossible task of divining the content of any one norm from a nearly infinite universe of meaning. Somló succeeds in accounting for a much more generalized concept of law, i.e. one which aligns much more closely with law's principle condition - sovereignty. However, in doing so, Somló seems to destroy much of the foundation which theorists have used in attempting to develop a 'scientific' theory of law.

Let us now look at the possibilities of regaining such a foundation in Somlós own theory.

\section{PLURALE TANTUM}

Since the concept of a norm requires that its claim be acted upon, each system of norms, through its own author, is completely independent of every other system of norms. Every system is able to lay claim without recourse (or concern) for other kinds of norms. Thus, every system of norms delineates itself. ${ }^{15}$

Whatever is sovereign at one point in time need not be the sovereign at another. Even if the establishment of one and the same sovereign can be postulated, there is no guarantee that the norms of any one governmental body, i.e. a secondary source, actually reflect the will of the sovereign and therefore are to be counted as law. Even if they do reflect the sovereign's will today, there is no guarantee that they will do so tomorrow. However, if the sovereign is that entity or person which enjoys a generalized habit of obedience on the part of subjects and if legal norms are those norms which issue from a sovereign, it must follow that legal norms are those that are generally and habitually obeyed. Somló insists that this 'generalized' quality of the law, i.e., that a sovereign and therefore also a legal system can only exist if it encompasses a sufficiently broad scope of human conduct, results in the fact that no one legal norm can be understood or even conceptualized as an isolated entity. The legal norm can only be understood as a plurale tantum, ${ }^{16}$ i.e. in the plural form.

14 See Somló (1927) §§ 100, 101.

15 Somló (1927) § 28, p. 90: 'Da es zum Begriffe der Norm gehört, die Verwirklichung einer Forderung zu verlangen, so ist jedes durch einen besonderen Urheber von den übrigen Arten abgegrenzte System von Normen von diesen übrigen Arten vollkommen unabhängig. Jedes vermag zu fordern ohne Rücksicht auf die anderen Normarten, jedes System von Normen bestimmt dementsprechend seine eigenen Grenzen selbst.'

16 Somló (1927) § 30, p. 98: 'Aus dem hier entwickelten Begriff der Rechtsmacht folgt zugleich, dass es eine Rechtsnorm als isolierte Einheit, ohne dass sie zugleich einer Vielheit von Schwestern angehörte, nicht geben kann. Darin, dass eine Macht ein weites Gebiet von Lebensverhältnissen normativ ergreifen muss, um zu einer Rechtsmacht werden zu können, ist bereits die Erkenntnis enthalten, dass es eine Rechtsnorm für sich gar nicht geben kann, sondern dass solche in der Wirklichkeit immer nur als ein begriffliches plurale oder besser gesagt multum tantum vorkommen 
or, as Somló says, as one within a brotherhood of other norms. ${ }^{17}$ If this is the case, then the task of understanding the law can be nothing but the task of understanding volition as it exists in the interplay between sovereign and subject. As such, the task of legal science is not so much to identify particular legal norms or to identify a particular sovereign. Rather, it is to understand the nature of the legal order, this plurale tantum that governs the relation between the individual and the collective.

Somló insists that his theory is no longer an epistemological theory of law, but rather an axiological, or value-based theory. ${ }^{18}$ This certainly does not mean that Somló advocates for an ideological approach to law in which one value, e.g., patriotism or religion, determines the science of law. Rather, Somlós position is that proper jurisprudential activity lies in weighing norms, or value propositions, against each other. For Kelsen, the normativity of the law only persists within the sphere of secondary rules (governmental bodies). As such, there can very seldom be true conflicts of law and jurisprudential activity is therefore limited to the epistemological task of ordering administrative actions within the context of the legal system. Since conflicts rarely arise and, when they do, they can normally be finally resolved by following the hierarchical rules of the legal system, the Kelsenian jurist need never decide upon a question of value. For Somló, on the other hand, juridical inquiry can only be a question of value and, since all norms (moral, aesthetic, grammatical, etc.) can be seen as coming to us unfiltered, it is the jurist's first task to determine which of the multitude of norms are actually legal norms and which of the legal norms supersede each other in a system of norms. The method which Somló must employ in theorizing such a system of jurisprudence is neither solely axiological nor solely epistemological but rather necessarily both axiological and epistemological.

Somló follows his Neo-Kantian peers by insisting that legal science is a normative science in that its object clearly entails a system of norms. However, in contrast to at least Kelsen, Somló does not hesitate at all in acknowledging the importance of fact for legal science. A legal system can only be understood from the legal perspective as a system of norms, i.e., ought-sentences that seek to guide human conduct. However, much of any putative system of norms is simply incomprehensible if considered within a normative vacuum. Legal norms themselves issue from a sovereign (or in accordance with the basic norm). This sovereign itself (as well as the validity of the basic norm) depends on a general habit of obedience, which is ultimately a factual quality - even if Hart calls the same attribute a 'rule' of recognition. More importantly, as quoted from Somló above, legal norms want and demand to be followed. Somlós personification of norms is poetic. However, what he really means is that the sovereign, who immediately or mediately issues

können. Es ist damit zugleich der Wahrheit Ausdruck verliehen, dass dasjenige, was wir bisher als Rechtsnorm bezeichnet und zum Ausgangspunkt unserer Untersuchung gemacht haben, nur als Teil eines Ganzes gedacht werden kann. Der Begriff einer Rechtsnorm weist über sich selbst hinaus auf das Ganze einer von einem einheitlichen Urheber getragenen Vielheit von Rechtsnormen. Dieses Ganze nennen wir Rechtsordnung. See also § 112: 'Jeder Rechtssatz gilt und bindet nur in notwendiger Wechselwirkung mit einer unbegrenzten Zahl anderer Normen, die ihn näher bestimmen, einschränken, oder in näherer oder entfernterer Beziehung ergänzen... Es gibt gar keine einzelne Rechtsnorm für sich - die einzelne Rechtsnorm ist nur eine künstliche Isolierung -, es gibt nur Rechtsnormen, die in ihrem Zusammenhange gelten; es gibt nur eine Rechtsordnung, und nur dadurch, dass eine Norm dieser angehört, wird sie zu einer Rechtsnorm.'

17 Somló (1926) 44.

18 Somló (1927) § 30, p. 98. 
a legal norm, does so wanting the norm to be obeyed. If the issuance itself is expressed then it is a communicative act. Even if it is not express, the issuance in any case creates a normative relation between the sovereign and subject as they exist in fact. Whether as a communicative act or a mere normative relation, the legal norm cannot be understood as it exists in the legal system without taking into account the factual circumstance of the issuer who utters or implies the norm, nor of the addressee whose conduct the issuer seeks to direct. While as a strictly theoretical matter it is possible to view the legal norm outside of any such factual context, to do so ignores that that with which the law is actually concerned is the volition of individuals, whether sovereigns, subjects or administrative officials. This volition is incomprehensible without addressing the interplay of norm and fact in the intentionality of human beings. ${ }^{19}$

If every norm only exists as part of a whole, the plurale tantum, then the relation in question is not one between the individual and a particular norm seeking to guide his conduct, but rather one between an individual and the entirety of the normative order itself.

\section{THE LOGICAL SENTENCE}

Much of the Juristische Grundlehre, including most of the considerations outlined above, consists more of questions of sovereignty, state and collectives than of the analysis of the strict functioning of a system of norms. Questions of law presuppose questions of state and a general theory of law requires a preliminary investigation of the theory of state - the postulate of the norm as plurale tantum suggests as much. This approach is validated when Somló turns to analyzing legal norms proper at the beginning of the second part of the Juristische Grundlehre.

The most important passages for the present reconstruction can be found in the Sixth Chapter on 'Legal Norm and Legal Text', as well as the $11^{\text {th }}$ and $12^{\text {th }}$ Chapters, 'Sources of Law' and 'Legal Interpretation (and Application)' and, very importantly, Somlós posthumously published, uncompleted manuscript on a theory of validity and truth, Gedanken zu einer ersten Philosophie (1926). In these passages, Somló makes the first steps toward a theory of sentences, norms and meaning which capitalize on his innovative insights regarding norms and sovereignty discussed above. It is ultimately Somló's theory of language, likely influenced by Bolzano, ${ }^{20}$ that is the key to understanding his theory of sovereignty and normativity.

In the first paragraph, $\S 60$, of the Second Part of the Juristische Grundlehre, Somló makes a relatively innocuous observation in distinguishing the logical from the grammatical sense of the general sentence:

We would now like to return to the general concept of law, even traversing one step beyond. For this purpose we differentiate between the logical sentence, or sentence of meaning, and the grammatical sentence, or the sentence of speaking. ${ }^{21}$

19 For John Searle, institutional reality always consists in a status function, that is a norm, to which he attributes the variable , y' as it exists in the (factual) context , c'. Normativity can only be understood within its appropriate factual context. Outside of such context, as Kelsen's project attests, normativity loses all meaning and becomes a shell of itself.

20 See Somló (1926) 13.

${ }^{21}$ Somló (1927) § 60, p. 179: 'Wir wollen uns nunmehr vor allem zum Oberbegriff des Rechts zurückwenden und sogar noch einen Schritt nach oben hin über ihn hinaus tun. Wir unterscheiden zu 
Every sentence has a logical and a grammatical aspect. ${ }^{22}$ The grammatical aspect is that which is spoken (or written) at face value. The logical aspect is the meaning that is contained in the spoken sentence. Every normal, i.e. communicative, sentence must have a logical content, i.e. a meaning, and, at least within the realm of a verbal language, every meaning must be expressed within a grammatical form. Any given meaning could be expressed in a multitude of 'grammatical' sentences and any (normal) grammatical sentence presents a multitude of possible interpretations, i.e., possible meanings. This distinction itself is not novel. Somló himself indicates in the footnotes to $\S \S 60$ and 61 several predecessors and contemporaries who have made similar distinctions, including Kelsen ${ }^{23}$ as well as Windelband and Wundt, the latter of whom gave the name judgment (Urteil) to that which Somló calls 'logical sense' or 'meaning'.

What is interesting about this distinction for Somló is that it seems to lead him to a theory of legal norms quite unlike other theories held by his Neo-Kantian contemporaries and unlike any other legal theorists since, but which, at the same time, predicts a significant strand of the philosophy of language in the $20^{\text {th }}$ century, perhaps best exemplified by Wittgenstein's treatment of language, use and meaning in the Philosophical Investigations. It is highly relevant that, in developing a theory of norms as a theory of normative meaning connecting sovereign and subject, Somló is able to develop a robust alternative to the Kelsenian theory, an alternative that is at once value-laden, because of the role of meaning inherent in the contextualization of sentences, and positivistic, as a result of such meanings being created by us.

Somló states in $\S 60$ that the grammatical (spoken) sentence can be considered as an isolated sentence (isolierter Satz) whereas the logical sentence can be considered as the sentence in context (Satz im Zusammenhang). The typical method for understanding the grammatical, or formal, sentence lies in understanding the normal meaning of its constitutive words together with the grammatical relations expressed in the sentence. The logical sentence, on the other hand, cannot be determined exclusively by its grammatical form. While the grammatical form is one element in determining the meaning of a sentence, i.e. the logical sentence, there are many other circumstances which serve to fully contextualize it and thereby disambiguate its meaning. ${ }^{24}$

diesem Zweck den Begriff des logischen oder des Bedeutungssatzes vom Begriff des grammatischen oder des Sprachsatzes.'

22 The logical meaning of a sentence as described here has nothing to do with the logical operators or quantifiers which might be used in translating a grammatical sentence of a natural language into a symbolic and abstract form. Indeed, the notion that a logical meaning of a sentence can exist independently of its grammatical form stands quite at odds with the tenets of logical positivism developed by the Vienna Circle shortly after Somlós departure. Here, Somló stands firmly in Bolzano's footsteps and as a harbinger of the later Wittgenstein.

${ }^{23}$ See Kelsen (1923) 238, FN 1: 'Es wäre ein arger Irrtum, wollte man den Rechtssatz, der erst aus den konkreten Gesetzen herauskonstruiert werden muss, mit einem der Sätze im grammatischen Sinne identifizieren, aus denen die konkreten Gesetzen aufgebaut werden. Es ist selbstverständlich, dass aus rein ästhetisch-stilistischen und auch aus anderen gesetztechnischen Gründen die eine Rechtspflicht statuierende ideale Norm mit allen ihren wesentlichen Bestandteilen tatsächlich auch im konkreten Gesetze nicht in einem einzigen Satz stilisiert wird, sondern hier in zahlreiche Sätze verschiedenster Struktur aufgelöst, ja sogar häufig auf zwei oder mehrere Gesetze verteilt erscheint. Sache der juristischen Konstruktion ist es, die ideale Norm aus diesen Teilen zusammenzusetzen.'

${ }^{24}$ Somló (1927) § 60, p. 181. 
In a way, Kelsen also draws the same basic distinction (FN 22). However, his distinction is much more formalistic in nature. Kelsen rightly points out that the grammatical sentence 'Murder shall be punished with ten years' imprisonment' cannot be understood as a legal norm (Rechtssatz) without taking into account other complementary grammatical sentences such as 'Murder is the unlawful killing of another human without justification'; 'Imprisonment is the forced confinement by the state to an institution', etc. Kelsen would make the unobjectionable claim that a single sentence written in a legal code is itself rarely if ever a sufficient basis for understanding the actual legal norm which it is meant to express. Instead, in order to properly identify the applicable norm, one would have to first set out all other relevant textual evidence, e.g., the applicable constitutional, legislative, and administrative provisions. Only upon considering this evidence would it be possible to make a proper judgment about the legal norm underlying the given text. What Kelsen does not seem to advocate is that the jurist would need to consult extra textual sources. Kelsen's proposed method is one of rule formalism or rule empiricism. Once the jurist's consideration extends beyond the admissible textual sources, the jurist then ceases trying to understand the legal norm as it exists and instead himself becomes involved in legislation. ${ }^{25}$ Such activity would no longer involve knowing but rather willing. ${ }^{26}$ Kelsen's caution in the face of politicizing the judiciary is well-placed and his position with respect to textual interpretation largely reflects contemporary jurisprudential orthodoxy as a practical matter. Nonetheless, Kelsen's empirical approach to interpretation reflects his empirical and relativistic approach to the concept of law in general which, upon closer examination of Somló's insights, must be rejected.

Somlós main points applying the distinction between the grammatical and logical sentence are insightful in this regard, indicating the limitation of an overly formalistic concept of law and the naïve understanding of sovereignty and meaning which it entails. On the one hand, Somlo states that there are limitations regarding how the sovereign can change existing law. For example, it could be the case that legislation is issued which, despite its compliant grammatical 'ought' form and formal compliance with legislative procedure, actually does not contain a normative meaning or contains a normative meaning which adds no normative content to the existing system, i.e., is

${ }^{25}$ Kelsen (1934), § 39, p. 99: 'Sofern bei der Gesetzesanwendung über die dabei nötige Feststellung des Rahmens, innerhalb dessen sich der zu setzende Akt zu halten hat, hinaus noch eine Erkenntnistätigkeit Platz greifen kann, ist es nicht eine Erkenntnis des positiven Rechts, sondern anderer Normen, die hier in den Prozess der Rechtserzeugung einmünden können; Normen der Moral, der Gerechtigkeit, soziale Werturteile, die man mit den Schlagworten Volkswohl, Staatsinteresse, Fortschritt, u.s.w. zu bezeichnen pflegt. Über deren Geltung und Feststellbarkeit lässt sich vom Standpunkt des positiven Rechts nichts aussagen.'

26 Kelsen (1934), § 39, p. 99: '[Die Reine Rechtslehre] zerstört die Meinung, dass im Wege der Erkenntnis Normen neu geschaffen werden könnten; eine Meinung die letztlich dem Bedürfnis entspringt, sich das Recht als eine feste Ordnung vorzustellen, die das menschliche Verhalten, insbesondere aber die Tätigkeit der Rechtsanwendenden Organe, der Gerichte vor allem allseits bestimmt; so dass deren Funktion und sohin auch die Interpretation nur als das Finden schon vorhandener und daher nur in einem besonderen Verfahren aufzudeckender Normen anzusehen ist.' 
redundant, or is incomprehensible within the system. ${ }^{27}$ Even if legislation is enacted which does succeed in expressing a normative meaning or shifting the normative framework, such a norm must and can only be understood within the context of the entirety of the legal system. ${ }^{28}$ A legal definition, but also a legal norm, is not any less binding than any other norm issuing from the sovereign. However, it is also not any more binding. ${ }^{29}$ Somló concludes his discussion on this point by stating:

The goal of [jurisprudence] is to reproduce the relevant normative content. However, in doing so, it need neither use the same words as the legislator nor even the same concepts. Indeed, one of the jurist's most noble tasks is to formulate in appropriate concepts the normative content the jurisprudential method has determined. ${ }^{30}$

This particular discussion in $\S \S 60-62$ as well as $\S \S 110-115$ applies directly to the interpretation of written texts. However, Somlós scope, and the importance of the general distinction between logical and grammatical sentences, extends far beyond textual interpretation. Legal formalism acknowledges that any written law can be ambiguous, but establishes rules for resolving any ambiguity in favor of 'sticking to' the text. Somlo's theory presents quite the opposite approach. For Somló, that which is real and valid about a norm has no inherent connection to that which is written down, although the written text is certainly one evidence among many. For Somló, the logical sentence exists independently of any expressed form and is conditioned only by all other logical sentences with which it co-exists.

Most jurists would readily acknowledge that the structure of law involves at its core the use of force by a state against individuals and that, at least in a fairly developed legal system, the means by which such force is carried out is through the written word. This is certainly also true for Somló. And yet, I believe that Somló was on to something much more fundamental in the Juristische Grundlehre with his concept of sovereignty as variable, the legal norm as plurale tantum and the distinction between logical and grammatical sentence. Somló was working on a general theory of the collective as expressed in the law.

27 Somló (1927) § 62, p. 185: 'Ob nun in irgendwelchen von der Rechtsmacht ausgehenden Sätzen überhaupt Normen enthalten sind oder nicht, ist eine Tatsachenfrage. Findet sich in einem Gesetz z.B. eine Einteilung, die zu seinem Verständnis überhaupt nichts beiträgt und die auch vom Gesichtspunkt des Wortgebrauchs des Gesetzgebers gänzlich unerheblich ist, so ist sie keine Norm.

28 Somló (1927) § 62, p. 186: 'Sie [legal definitions] dürfen, wie die Sätze der Rechtsmacht überhaupt, nicht aus ihrem Zusammenhang herausgerissen für sich und auch nicht rein ihrer grammatischen Form nach beurteilt werden, sondern sind mit den übrigen [i.e. definitions and other legal norms] in Zusammenhang zu bringen. Wenn dies gelingt, so gewinnen sie Anteil an der logischen Struktur der übrigen Sätze und erweisen sich dadurch als Normen.'

${ }^{29}$ Somló (1927) § 62, p. 186: 'Die in der Form einer Legaldefinition ausgedrückte Norm ist also einerseits um nichts weniger verbindlich als andere Normen der Rechtsmacht; sie ist aber andererseits natürlich auch um nichts verbindlicher.'

30 Somló (1927) §62, p. 187: '[Jurisprudenz] hat den Norminhalt wiederzugeben, aber sie braucht es weder mit den Worten zu tun, die der Gesetzgeber dazu verwendet hat, noch mit denselben Begriffen; ja es ist eben eine ihrer vornehmsten Aufgaben, den ermittelten Norminhalt in entsprechendere Begriffe umzuleeren.' 


\section{SOVEREIGNTY AS A FUNCTION OF VALIDITY - CLOSING CONSIDERATIONS}

The meeting place of the factual and the normative is the human mind. A sovereign can have a desire, issue a norm on account of this desire and thereby change the world. A subject can understand a norm and change his conduct on its account. Each of the two preceding sentences presents a sequence of a fact interchanging with a norm which interchanges with a fact. In each such case, normativity cannot be understood outside of the fact of human intentionality. In each such case, normativity can also not be understood outside of language. Language is that which connects normativity to the mind. Only if a language is capable of creating sentences with absolute validity can a mind be rational, connected to the world. ${ }^{31}$ Of course, such sentences are not the grammatical sentences of fact which themselves have no meaning, but rather the logical sentences of normativity.

This paper asserts, with Somló, that legal norms are to be understood as a plurale tantum, that expressions of law derive from a logical form and, the title of this section, that sovereignty is actually a function of validity. Somló says that the initial perception is nothing but evidence or perhaps intuition and that these raw impressions of the world must first be formed into thoughts, sentences, before any consideration of validity or correctness can be undertaken. ${ }^{32}$ What holds of mere perception, is also true of communication. ${ }^{33}$ All that exists in nature are individuals faced with each other. In order to communicate, or to issue a directive, an individual must be able to formulate in language that which he wills internally and the other, on the basis of such formulation, together with all other evidence and intuition, must try to understand not just that which was expressed as the outer will, but also that which exists within the other. Grammatical sentences are all that can ever be perceived. Yet, the grammatical sentence as fact is useless. It is only the sentence as thought or meaning, the logical sentence, which serves as the normative glue that binds us to one another. ${ }^{34}$

31 See Bolzano (2000) § 17, p. 97, 98: 'Wer nichts für Gewiss hält, der kann sich der Vernunft, dieser edelsten Gabe des Himmels, gar nicht bedienen zu den erhabenen Zwecken, zu welchem sie uns von Gott verliehen worden ist. Denn da er das Vermögen, Gutes vom Boesen, Wahres vom Falschen zu unterscheiden, nicht zumutet, da er nicht einmal glaubt, dass es irgend etwas, das an sich selbst wahr und gut ist, gebe: wie sollte er Lust haben, bei allem was er tun oder nicht tun will, seine Vernunft erst zu Rathe zu ziehen! Wie sollte er aufgelegt sein, seine Begierde und; Neigungen durch ihre Aussprüche beherrschen zu lassen? Untätig, oder höchstens beschäftigt mit Dingen, die einen augenblicklichen Genuss gewähren, ist er nicht fähig, je etwas Grosses zu Stande zu bringen, weil alles Grosse erfordert, dass man den Aussprüchen und Berechnungen seiner Vernunft vertraue.'

32 See Somló (1926) 42: 'Das zu Messende, das Material der unbedingten Richtigkeit war und ist etwas Psychologisches. Dieses Psychologische führt den Namen Evidenz oder auch Intuition. Alles Evidente oder Intuitive ist uns daher nur eine Fragestellung nach unbedingter Gültigkeit selber. Evidenzen und Intuitionen können einander widersprechen, d. h. sie können auch irrig sein.'

33 Somló (1927) § 111: 'Überall, wo die Äußerung eines psychischen Vorganges darauf angelegt ist, von anderen aufgenommen zu werden, gilt es, die Kluft zwischen zwei Psychen zu Überbrücken. Es bedarf einerseits einer Äußerung des Innenlebens und einer Enträtselung dieser Äußerung andererseits.'

${ }^{34}$ Bolzano says that there are necessarily so many kinds of formulations of sentences (thoughts) as there are possibilities for an individual to express itself. See Bolzano (2000) § 21, p. 111: 'Es muss notwendig so viel Arten von Sätzen geben, als dem Geiste Handlungsweisen des Setzens zukommen.' 
Validity can never attach to the factual itself but rather requires the formulation of a sentence, a thought in which a predicate is brought into connection with a subject. Bolzano held that prescriptive statements also determine states of affairs such that truth and validity could be predicated of such statements:

The sentence 'I wish that Cajus were an honest man.' leaves open the relation which exists between Cajus and honesty. However, Cajus and honesty are also not the subject and predicate of this sentence. The proper subject of this sentence is the speaker. The predicate is the speaker's wish that Cajus be honest. ${ }^{35}$

A speaker is neither valid or invalid; Caius himself is neither valid nor invalid; honest men themselves are neither valid nor invalid - each of these alone are merely facts and facts are always conditional, that is, they do not exist necessarily but are conditioned by their givenness in the world. The only thing which is unconditional is a meaning yet meanings themselves only have validity in a community of meanings - the plurale tantum. ${ }^{36}$ A speaker's wish for Caius to be honest i.e., that Caius should be honest, will either be valid or invalid depending on a host of other sentences. Because facts are always conditional, the validity of this statement will not depend on any state of mind, neither of the speaker nor of Caius but only on the normative order in which the speaker and Caius act.

Kelsen, along with most other theorists, presupposes the existence of the sovereign. As a result for Kelsen, the sovereign itself is never part of the sentence seeking validation and all that Kelsen can validate in his theory of norms is the proposition - 'Caius should be honest'. Kelsen is correct that such propositions cannot be contradicted with the result that Kelsen must limit himself to the 'relative' validity of a hierarchy of administrative norms. However, the picture is drastically different if, with Somló, the concept of sovereignty is open. Suddenly, the operative proposition is no longer 'Caius should be honest' but rather 'S states that "Caius should be honest". Whether S stating that 'Caius should be honest" is a valid statement depends on a jurisprudential inquiry that will entail determining, through the principle of non-contradiction, whether $\mathrm{S}$ in this case is sovereign (primary source of law) or speaks for the sovereign (secondary source of law) and, if so, how 'Caius should be honest' fits within the entirety of the legal order, the norm as plurale tantum.

In denying the possibility of a logic of norms, Kelsen denies that there is a universe of meaning in the legal realm between subjects. Somlós work stands for the proposition that this is nonetheless possible through the absolute validity of truth which our reason requires. At the very end of his Gedanken zu einer Ersten Philosophie, in what remains as a fragment, Somló discusses the requirement of absolute validity bottoming out in the concept

35 Bolzano (2000) § 22, p 115: 'Der Satz: ich wünschte, dass Cajus ein ehrlicher Mann wäre, läßt freilich das Verhältnis, das zwischen Cajus und Ehrlichkeit obwaltet, unbestimmt, Cajus und Ehrlichkeit sind aber auch nicht Subject und Prädicat in diesem Satz; sondern das eigentliche Subject desselben ist der Sprechende, und das Prädicat, der Wunsch, daß Cajus ein ehrlicher Mann wäre.'

36 See Somló (1926) 25: 'Solange einem Sinn noch etwas tatsächliches anhängt, zieht ihn dieser Erdenrest unerbittlich in die Niederungen des Bedingten hinab. Schlechthin unbedingt sein kann also gar niemals eine Tatsache, sondern nur eine Bedeutung, ein Sinn. Der Sinn oder die Bedeutung muss also sorgfältig von jedem Erhobensein, Gegebensein, Dasein, Existenz, kurz von jeder Tatsächlichkeit losgelöst werden.' 
of truth. ${ }^{37}$ The validity of an expressed norm (Kelsen's Rechtssatz) is always conditional upon the fact of its expression and therefore can never be absolute. Kelsen is therefore correct in stating that a norm as norm, even the basic norm, is never absolute. For Somló though, the actual norm, that which bears meaning, cannot be reduced to its mere factual expression. As a bearer of meaning, the norm exists not as a grammatical sentence, isolated in fact, but rather as a logical sentence, embedded in the context of the plurale tantum. Truth can be predicated of such a system of norms because of its coherence, sovereignty because of its generality.

This conception of normativity as a logical whole is only possible given Somlós insistence on the existence of logical sentences, or norms in context with other norms connecting issuers and addressees. An individual norm can never be followed on its own but only such a norm as part of a whole, the idea of normativity as a plurale tantum has as consequence the idea that an individual should abandon preferences born out of facticity in favor of normativity (or meaning) constituted by the collective. Phrased in Kantian terms, this means that an individual should only pursue such courses of action that, when generalized, are in conformity with the system of norms, or normativity, generally. The normative plurale tantum shares with the categorical imperative the same admonition favor the meaning of the collective over the facticity of the brute, favor order over disorder.

The possibility of creating such meaning and order is a simple requirement of human rationality. The imperative of creating such a system of order and meaning must be the requirement of legal positivism as the science of law.

\section{LITERATURE}

Bix, Brian, 'John Austin' in Zalta, Edward N. (ed), The Stanford Encyclopedia of Philosophy (Stanford University Spring 2018 Edition) $<$ https://plato.stanford.edu/archives/spr2018/entries/austin-john/> accessed 10 October 2018.

Bolzano, Bernard, Wissenschaftslehre. (Frommann-Holzboog 2000).

Hart, Herbert Lionel Adolphus, The Concept of Law. (2d edn, OUP 1994).

Kelsen, Hans, Reine Rechtslehre. (1st edn, Leipzig 1934).

Kelsen, Hans, Hauptprobleme der Staatsrechtslehre. (2d edn, Mohr 1923).

Searle, John, The Construction of Social Reality. (The Free Press 1995).

Somló, Felix, Gedanken zu einer Ersten Philosophie. (Walter de Gruyter 1926).

Somló, Felix, Juristische Grundlehre. (2nd edn, Meiner 1927).

37 See Somló (1926) 104: Es ist damit nicht gesagt, dass es neben dem Wahrheitsanspruche andere Geltungsansprüche nicht gibt, - soll es sie jedoch geben, so müssen sie sich ihre Bestätigung vom Wahrheitsanspruche aus erbitten... Denn wenn wir nach ihrer Unbedingtheit fragen, was wir zu tun gezwungen sind, fragen wir ja bereits nach einer Wahrheit. Die Untersuchung der Unbedingtheit des Geltungsanspruches: du sollst nicht töten, erfordert bereits seine Übersetzung in den Satz, es ist wahr, dass das Gebot, du sollst nicht töten, unbedingt gilt. Der Gegensatz von 'du sollst nicht töten', wäre blos: du darfst oder gar du sollst töten. In dieser Schicht lässt sich aber keine Untersuchung der Unbedingtheit führen. Nun steckt aber auch im unbedingten Geltungsanspruch des Satzes, du sollst nicht töten, das Problem, das wir seiner nur als eines von uns erhobenen gewiss sind, und dass er trotz dieser seiner subjektiv bedingten Erhobenheit, ein unbedingter zu sein angibt. Der hierin verborgene Widerspruch lautet also bereits: dieser Anspruch ist kein unbedingter. Das Problem lautet daher doch nur so, ob es wahr ist, dass dieser Anspruch unbedingt ist. Wir haben also unseren unbedingten Sollsatz 'du sollst nicht töten' in den unbedingten Aussagesatz: es ist wahr, dass das Gebot, du sollst nicht töten unbedingt gilt, übersetzt. Der Sinn seiner unbedingten Geltung ist ein Wahrheitssinn. Mithin gibt es gar keine andere unbedingte Geltung als die der Wahrheit. 